\title{
Н.А. Непомнящих
}

Институт филологии СО РАН, Новосибирск

\section{«Замятинский текст» в произведениях Л.М. Леонова: повесть «Evgenia Ivanovna»}

Имена Леонова и Замятина впервые были поставлены рядом еще в 1920-е годы. В последнее десятилетие исследователи вновь заговорили о близости идейных и эстетических исканий обоих писателей [Матушкина, 1997, с. 82-83; Сорокина, 1997, с. 170-175; Исаев, 1997, с. 41-43; Зозуля, 2000, с. 261-271; Якимова, 2004, с. 175-191]. В последнем романе Леонова «Пирамида» (1994) в сюжетной линии Вадима Лоскутова налицо сразу несколько маркированных именем Замятина структур: контурно за судьбою Вадима проступают биографические соответствия судьбе Замятина, далее сама эта линия сюжетно отсылает к жанру антиутопии [Листван, 2004], и основное - в эпизоде посещения Вадимом стройки гигантского памятника Вождю аллюзивно и напрямую цитируется роман «Мы» Замятина [Непомнящих, 2006, с. 367-387]. Все это в совокупности дает основания обратиться рекурсивным взором к предшествующему творчеству Леонова ${ }^{1}$.

Первое, что бросается в глаза, когда рядом сополагаются повесть «Evgenia Ivanovna» и имя Замятина - это полное совпадение имени-отчества главной героини, давшее название повести, с именем и отчеством Евгения Ивановича Замятина. Вполне закономерным является вопрос, насколько это совпадение случайно? Соответственно, становится небезразличным, какова в целом стратегия называния именами собственными у Леонова. Накопленные разными исследователями наблюдения дают интересные результаты, которые пока нигде не были обобщены, нет работ, специально посвященных леоновской ономастике. Условно можно разделить те собственные имена из произведений Леонова, которые привлекали внимание исследователей, на 3 группы: 1) имена литературных персонажей: Грацианский («Соборяне» Лескова - «Русский лес» Леонова), Иван Флягин («Очарованный странник» Лескова - «Белая ночь» Леонова), Матвей («Пирамида Леонова - два горьковских Матвея: «Исповедь», «Матвей Кожемякин»); 2) имена-анаграммы, шарады; 3) имена реальных людей: Сергей Чадаев («Бродяга», Леонов) $)^{2}$. Думается, что список имен реальных людей, судьбы которых имели в сознании Леонова свое символическое, знаковое значение можно продолжить. Проиллюстрируем этот тезис на примере повести «Записи Ковякина». Действие происходит в захолустном городишке с говорящим названием - Гогулев. В имени главного героя «Ковякин» Л.П. Якимова усматривает анаграмму фамилии горьковской повести «Кожемякин». [Якимова, 2004]. Внутренняя полемическая заряженность «Записей Ковякина» очень велика, подтекст повести только начинает прочитываться. На аспект спора с горьковским окуровским циклом и Матвеем Кожемякиным обратила внимание Л.П. Якимо-

\footnotetext{
${ }^{1}$ Плодотворность «рекурсивного» чтения Л. Леонова впервые продемонстрировала в своих работах Л.П. Якимова

${ }^{2}$ А.Г. Лысов усматривает в коллизиях этой повести рассказ о трагедии Сергея Есенина. См.: [Лысов, 2005].
} 
ва. Но горьковская линия здесь не единственная. Произведение словно соткано из самых разнообразных аллюзий, одна из которых заявлена уже в названии города - «Гогулев». В этом Гогулеве собраны воедино многие черты, мотивы, герои произведений о провинции самых разных русских писателей: перед нами словно «коллективный» литературный портрет русского захолустья. Отчетливо прослушиваются мотивы замятинских «уездных повестей», в особенности повести «Алатырь». Однако было бы несправедливым видеть в «Записях Ковякина» лишь набор литературных стереотипов, собранных в своеобразную коллекцию.

В текст неумолимо вторгаются реальные события революции, и именно они заставляют сделать «поправку» во многих литературных, умозрительных представлениях. В письме, с которого начинается повесть, среди прочего сообщается, что «умер Василий Васильевич от простуды» [Леонов, 1981a, с. 285]. Думается, что подобным образом автор отмечает какие-то важные для себя события. Возможно, что таким образом он говорит о смерти Василия Васильевича Розанова. Сама повесть представляет собой записи, записки местного чудака, «маленького человека», не слишком образованного, простоватого, но явно симпатичного автору, что, возможно, должно напомнить читающему, кроме прочего, и о скандальном всего какое-то десятилетие до того «Уединенном» (1912) Розанова, где автор скрывается за подобною же маскою. Финал повести явно окрашен в апокалиптическую тональность. Для маленького провинциального городишки приключившаяся «смута» является светопреставлением, что отсылает уже к розановскому «Апокалипсису наших дней».

Косвенным подтверждением тому, что перед читающим не простое совпадение имени-отчества какого-то всего лишь раз упомянутого персонажа с именем известного русского философа, автора «Апокалипсиса нашего времени», может служить аналогичная ситуация в «Пирамиде». Лишь один раз упомянут в разговоре супругов Филуметьевых Владимир Михайлович - друг профессора, который «поплатился за свой несчастный диагноз» [Леонов, 1994, c. 209]. Казалось бы, малозначащая реплика, просто характеризующая обстановку доносительства и тотальных репрессий тридцатых годов. Однако «знаменитый дружок» профессора Филуметьева не выдуман - это Владимир Михайлович Бехтерев, которому приписывают слова «сухорукий параноик», после осмотра Сталина. Семья Бехтеревых всегда была уверена, что Владимира Михайловича убили и именно по этой причине [Мороз, 1988, с. 12].

В свете изложенного представляется более чем вероятным, что имя свое Евгения Ивановна получает вовсе не случайно: имя является тем герменевтическим указателем, который задает угол зрения, позволяющий увидеть «маркированные» замятинской темой структурно-смысловые элементы. Дальнейший анализ текста подтверждает это предположение. Название повести написано латиницей. Заглавием задана важная для понимания оппозиция «русского» и «чуждого» (иностранного, европейского, английского), весьма ощутимая для творческого сознания Замятина. Одновременно начертание русского имени латиницей - это знак, в котором полюса этой оппозиции объединены, сразу представляя и свое, и чужое. Такое начертание перед прочтением повести заставляет думать, почему нельзя было написать название по-русски, а по ее прочтении производит впечатление трагичности.

За обозначенной темой - судьбой молодой женщины, вынужденной русской эмигрантки - вырисовывается общая глубинная проблема, вокруг которой в горячих словесных поединках героев разворачивается одна из пружин внутреннего сюжета повести: размышления об оправданности отъезда. Полемика между теми, кто остался «здесь», и теми, кто теперь «там», на Западе, была в те годы актуальна не только для Леонова. В ахматовской лирике также существует оглядка на тех, кто уехал, звучит не утихающий личный спор, просчитываются 
возможные последствия вероятного, но невозможного для Ахматовой отъезда ${ }^{1}$. Евгения Ивановна, с ее трезвым пониманием невозможности здесь больше быть, и одновременно с осознанием, что вне России она быть и жить не может, очень близка как внутренней трагедии самого Замятина, так и многих русских, вынужденных после революции покинуть родину.

Родиной героини повести, как и Замятина, является глухой провинциальный городок: мальвы в палисаднике, пыль, тишина «уездного» существования. Трижды он появляется в повести: в начале как «степной городишко», потом как смазанный фотографический отпечаток площади на обрывке советской газеты, бережно хранимом Евгенией Ивановной. И, наконец, в воспоминаниях и в просьбе героини к мужу «побродить в одном степном городке» с «отфильтрованной снегопадами тишиной», «с очищающей силой летней степной грозы», с мальвами и помидорами в огородике уже умершей мамы. Здесь, в сфере авторской оценки, проходит решающий водораздел между Замятиным и Леоновым: для Замятина «Уездное», провинция - это мир пошлости, наводящей тоску, мир отупения, беспросветности. Леонов, напротив, поэтизирует провинцию и не только в этой повести, но и в более ранних произведениях. Тут его позиция в большей степени соотносима с позицией Лескова, считавшего, что именно провинция является «настоящей», глубинной, исконной, подающей надежды Россией.

«Я сделана из этой земли, мой милый», - говорит героиня новому мужу англичанину. «Англичанин» - известное прозвище Замятина в писательской среде по возвращении его из Англии. Ремизов иронизировал: «Замятин из Лебедяни, тамбовский. Чего русее, и стихия его слов отборно русская. Прозвище: “англичанин”. Как будто он и сам поверил - а это тоже очень русское...». В этих словах Ремизова очень четко обозначена антитеза, имевшая значение для Замятина: «русское - английское и в целом европейское». На то, что эта антитеза, безусловно, существовала, указывают разные исследователи, например, О. Михайлов [Михайлов, 1989]. Лондон для Замятина - символ каменного и механического. В статье об Уэллсе звучит так: «Представьте себе страну, где единственная плодородная почва - асфальт, и на этой почве густые дебри только фабричных труб, стада зверей только одной породы - автомобили, и никакого весеннего благоухания - кроме бензина. Это каменная, асфальтовая, железная, бензинная, механическая страна - называется сегодняшним XX столетия Лондоном» [Михайлов, 1989, с. 13]. Героиня Леонова задает мужу-англичанину вопрос о Лондоне: «Говорят, в этом городе только дым да камень и ни капельки души... неужели верно это?». [Леонов, 1981, с. 134]. Причем этот вопрос никак не подготовлен предшествующей биографией героини: выросшая в захолустном русском городке, скитавшаяся в Константинополе и Париже, что она может знать о Лондоне? - и кто мог ей это говорить? Данный вопрос скорее диктуется внутренней логикой полемики с Замятиным. Вопрос о душе и для Замятина, и для Леонова, испытавших сильнейшее воздействие Достоевского, отнюдь не праздный. В контексте эпохи даже оппозиционный. Но в повести вопрос о городе из камня без души воспринимается как знак-отсылка к Замятину тем более, что в сознании самого Леонова такой четкой оппозиции русского и английского / европейского не было. Ответ, данный англичанином, как раз свидетельствует об этом: он и в Лондоне готов найти те камни, что свидетельствуют о духовной культуре человечества. Возвращаясь к Замятину и знаковости его фигуры, ее неявного присутствия в тексте, укажем на противопоставленность русской Евгении Ивановны англичанину. Ее благодетелем, спасителем мог оказаться человек любой другой национальности. Но это именно англичанин. Прозвище Замятина, знак его «английских повестей».

\footnotetext{
${ }^{1}$ Подробнее о мотиве эмиграции в лирике Ахматовой см. [Бобышев, 1990].
} 
Противопоставлены герои не только по национальному признаку. Ключевым является непонимание иностранца той странной болезни, от которой увядает молодая жена. Объяснений которой нет и у докторов: физически они не находят отклонений. Леонов называет ее ностальгией. Причем, автор формулирует понимание ностальгии англичанами, довольно иронически. Евгения Ивановна также не может объяснить мужу, почему она не может разлюбить свою родину, столь сурово с нею обошедшуюся. Муж, ссылаясь на Дидро, говорит, что она должна быть свободна от обязательств и прочих чувств перед тем, кто платит ей ненавистью. Но Евгения Ивановна с ним не согласна. Как поступать, если отечество стреляет в тебя? - вопрос, проблема, на которую Леонов неоднократно указывал в автокомментариях к повести. Как можно любить то, что тебя ненавидит? Замятин выехал заграницу, но не менял своего советского паспорта, в эмиграции держался особняком. Замятин остался собою - любящим, по его же определению, свою родину «белой любовью». Он не ругал Россию, не мог платить ненавистью. Замятину была знакома эта болезнь: «Эта любовь, требующая все или ничего, эта нелепая, неизлечимая, прекрасная болезнь - болезнь не только Сологуба, не только Дон Кихота, не только Блока (Блок именно от этой болезни и умер) - это наша русская болезнь...» [Замятин, 1990, с. 461].

«Это типично русская болезнь», - слова Замятина в эссе о Сологубе. В повести Леонова Евгения Ивановна умирает от послеродового осложнения: «Британские медики объяснили ему гибель жены послеродовым осложнением; диагноз был бы точнее, если бы, помимо истории болезни, они располагали скудными сведениями о своей пациентке, изложенными в этой повести» [Леонов, 1981, с. 195]. Сам Замятин также был болен этой типично русской болезнью: без России он не мог ни писать (ничего в эмиграции не создал), ни жить. Неудивительно, что смерть героини в повести приходится на весну, как и смерть Замятина. Предпоследний абзац повести Леонова содержит пассаж о том, что все попытки «не испорченных западной цивилизацией наших беглецов вывезти с собою горстку сурового зимнего снежка в страны более умеренного климата завершались неудачей, - он неизменно таял». [Леонов, 1981, с. 195]. Это финал произведения. Пока не удалось установить, был ли знаком Л. Леонов с автобиографией Замятина, датированной 1928-м годом, начало которой очень необычно для такого устойчиво-шаблонного жанра. Она начинается первым детским воспоминанием: мальчику показывают на блюде снег, который буквально на глазах неведомо куда исчезает. Но аллюзия слишком явная, к тому же расположена в «сильной», маркированной позиции текста - финале, что дает некоторые основания считать ее значимой. Тем более, что тем самым замыкается круг: «заглавие» - имя Замятина (также сильная позиция) - финал.

Памятуя о значимости замятинского текста в «Пирамиде» и имея в виду параллели и переклички идейных и эстетических поисков в 1920-е годы, логично предположить, что совпадение имени героини с именем Замятина внутренне обосновано. Для Леонова Замятин, по-видимому, был знаковой фигурой, проявлявшей его собственные «болевые точки» и оставившей пожизненный след в его произведениях.

\section{Литература}

Бобышев Д. О так называемых «антиэмигрантских» стихах А. Ахматовой // Записки Русской Академической группы в США. Т. 23 (Лермонтов, Ахматова). 1990.

Замятин Е.И. Избранные произведения. М., 1990. 
Зозуля Н.Ю. Образ земли обетованной в романе Л. Леонова «Пирамида» и роман Е. Замятина «Мы» // Русская классика XX века: В. Набоков, А. Платонов, Л. Леонов: Сборник научных трудов. Саратов, 2000.

Исаев Г.Г. Е. Замятин и Л. Леонов // Творческое наследие Евгения Замятина: взгляд из сегодня. Кн.6. Тамбов, 1997.

Леонов Л.M. Evgenia Ivanovna // Собрание сочинений: В 10-ти т. Т. 8. М., 1981.

Леонов Л.М. Записи некоторых эпизодов, сделанные в городе Гогулеве Андреем Петровичем Ковякиным // Леонов Л.М. Собрание сочинений: В 10ти т. Т. 1. М., $1981 \mathrm{a}$.

Леонов Л.М. Пирамида. М., 1994.

Листван Ф. Роман Л. Леонова как антиутопия // Русская литература XIX в.: поэтика мотива и аспекты литературного анализа. Новосибирск, 2004.

Лысов А.Г. «Березовый меридиан»: Сергей Есенин и Леонид Леонов. Ульяновск, 2005.

Матушкина В.И. Е. Замятин и Л. Леонов (к вопросу об эстетических взглядах) // Творческое наследие Евгения Замятина: взгляд из сегодня. В 6-ти кн. Кн. 2. Тамбов, 1997.

Михайлов О. Гроссмейстер литературы // Замятин Е.И. Избранное. М., 1989.

Мороз О. Последний диагноз // Литературная газета. 1988. 26 сентября. № 39 (5209).

Непомнящих Н.А. «Замятинский текст» в «Пирамиде» Л.М. Леонова // Материалы к словарю мотивов и сюжетов русской литературы. Вып. 7: Тема, сюжет, мотив в лирике и эпосе. Новосибирск, 2006.

Сорокина Н.В. Тема будущего в произведениях Е. Замятина и Л. Леонова // Творческое наследие Евгения Замятина: взгляд из сегодня. Кн. 4. Тамбов, 1997.

Якимова Л.П. Повесть Леонида Леонова «Записи Ковякина»: образ времени как фактор циклообразования // Материалы к словарю сюжетов и мотивов русской литературы. Вып. 6. Интерпретация художественного произведения: сюжет и мотив. Новосибирск, 2004.

Якимова Л.П. Семиотика пещеры в русской литературе 1920-х гг. // Критика и семиотика. 2004. № 7. 